\title{
Expanding horizons of active packaging: Design of consumer- controlled release systems helps risk management of susceptible individuals
}

\author{
Derya Boyacı, Ahmet Yemenicioğlu* \\ Department of Food Engineering, Faculty of Engineering, Izmir Institute of Technology, 35430, Gülbahçe Köyü, Urla, Izmir, Turkey
}

\section{A R T I C L E I N F O}

\section{Article history:}

Received 21 August 2017

Received in revised form 30 December 2017

Accepted 30 December 2017

Available online 3 January 2018

\section{Keywords:}

Antimicrobial film

Activate-at-home

Zein

Lysozyme

Soy protein

Risk management

\begin{abstract}
A B S T R A C T
The objective of this study was the development of zein based antilisterial films that contain a consumercontrolled and pH-triggered release mechanism for lysozyme (LYS). For this purpose, composite films were formed by mixing hydrophobic zein with hydrophilic soy protein isolate (SPI) or lentil protein isolate (LPI). Active property of films was formed by maintaining 30 to $50 \%$ of total LYS in free form $\left(\mathrm{LYS}_{\text {free}}\right)$. On the other hand, the $\mathrm{pH}$-triggered release mechanism was formed by exploiting attractive charge-charge interactions between LYS (pI: 11.4) and SPI or LPI (pI values $\approx 4.5$ ), and binding remaining

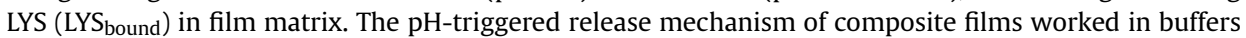
that had pHs varying between 4.3 and 7.3. The composite films bound majority of LYS between pH 5.3 and 7.3, but they released LYS at $\mathrm{pH} \leq 4.5$. The $\mathrm{pH}$-triggered release of LYS was achieved with zein-LPI films activated by acidification in packed cold-stored beef, lamb and smoked salmon. The zein-SPI films performed $\mathrm{pH}$-triggered LYS release in packed food with the exception of packed smoked salmon. The $\mathrm{LYS}_{\text {free }}$ and LYS bound released from pH-triggered films showed antimicrobial activity on Listeria innocua. Consumer-controlled release mechanisms enable increasing antimicrobial stress over pathogens during transfer from market to home and cold storage at home. Thus, such films could initiate personalized packaged food to help risk management of susceptible individuals.
\end{abstract}

(C) 2018 Elsevier Ltd. All rights reserved.

\section{Introduction}

The increasing threats of foodborne outbreaks related to raw, minimally processed or ready-to-eat food products have boosted the research in the field of active packaging technologies such as antimicrobial, antioxidant, and bioactive packaging (Cagri, Ustunol, \& Ryser, 2001; Lu, Zhu, Li, \& Chen, 2015; Lynch, Tauxe, \& Hedberg, 2009). Antimicrobial packaging is the most promising active packaging technology since it could be used as an effective hurdle to increase safety and/or shelf-life of food (Appendini \& Hotchkiss, 2002; Gennadios, Hanna, \& Kurth, 1997; Han, 2000; Ouattara, Simard, Piette, Bégin, \& Holley, 2000; Quintavalla \& Vicini, 2002). Antimicrobial packaging targets mainly the food surface on which microbiological changes occur most intensively (Appendini \& Hotchkiss, 2002). Thus, it uses lower amounts of antimicrobials than adding antimicrobials into bulk of food. The use of natural

\footnotetext{
* Corresponding author.

E-mail address: ahmetyemenicioglu@iyte.edu.tr (A. Yemenicioğlu).
}

antimicrobial compounds in edible films attracts a particular interest since health concerns and environmental problems originating from chemical food additives and plastics have been increasing continuously (Cha \& Chinnan, 2004; Han, 2003; PérezPérez, Regalado-González, Rodríguez-Rodríguez, BarbosaRodríguez, \& Villaseñor-Ortega, 2006; Suppakul, Miltz, Sonneveld, \& Bigger, 2003).

Hen egg white LYS is one of the most potential candidates for antimicrobial packaging since (1) it has a Generally Recognized as Safe (GRAS) status, (2) it shows good stability and activity in different films and food systems under refrigeration (Mecitoğlu et al., 2006; Ünalan, Korel, \& Yemenicioğlu, 2011), and (3) it has been tested extensively in major edible film materials (Cha, Choi, Chinnan, \& Park, 2002; Park, Daeschel, \& Zhao, 2004; Bower, Avena-Bustillos, Olsen, McHugh, \& Bechtel, 2006; Mecitoğlu et al., 2006; Joerger, 2007; Mendes de Souza, Fernández, López-Carballo, Gavara, \& Hernández-Muñoz, 2010). The antimicrobial mechanism of LYS originates from its lytic activity that causes splitting of the bonds between $\mathrm{N}$-acetylmuramic acid and $\mathrm{N}$-acetylglucosamine of the peptidoglycan in Gram-positive bacterial cell wall (Appendini \& 
Hotchkiss, 1997; Shah, 2000). Some Gram-positive pathogenic bacteria such as Staphylococcus aureus show extreme resistance against LYS (Sudağıdan \& Yemenicioğlu, 2012), but LYS shows high potency against the critical bacterial pathogen Listeria monocytogenes (Duan, Park, Daeschel, \& Zhao, 2007). It is essentially important to control contamination and growth of L. monocytogenes in food since this bacterial pathogen regularly causes deadly infections in pregnant women, and elderly and immunosuppressed people (Vazquez-Boland et al., 2001; ÁlvarezOrdóñez, Leong, Hickey, Beaufort, \& Jordan, 2015). Antimicrobial packaging could be used as a highly effective hurdle to prevent the growth of $L$. monocytogenes in risky foods that contaminate easily with this pathogen and enable its growth. For example, Min, Rumsey, and Krochta (2008) successfully employed LYS in whey protein films to control L. monocytogenes growth on smoked salmon. Ünalan, Arcan, Korel, and Yemenicioğlu (2013) employed LYS containing zein composite films to prevent the growth of L. monocytogenes in fresh cheese. In these studies it was aimed to maximize free LYS in the films by minimizing interactions and bonding between LYS and edible film matrix. The presence of free LYS ensures the initiation of enzyme release from films onto food surface and provides an antimicrobial activity.

Boyac1, Korel, and Yemenicioğlu (2016) have developed LYS containing whey protein based edible films with a novel concept named activate-at-home type packaging (ActiHome packaging). These authors employed this concept in preventing listerial growth in cold-smoked salmon. ActiHome packaging is a novel concept which means that packaging material is activated by consumers to form a hurdle for the development of critical pathogenic bacteria in food kept at home in refrigerators until consumption (Boyac1 et al., 2016). ActiHome packaging could be an alternative technology to reduce the risk of food poisoning from $L$. monocytogenes whose growth cannot be controlled by traditional packaging methods such as vacuum packaging (VP) (Duffes, 1999; Gram, 2001). Some studies have shown that it is possible to control L. monocytogenes growth in risky food by modified atmosphere packaging (MAP) containing elevated levels of $\mathrm{CO}_{2}\left(100 \% \quad \mathrm{CO}_{2}\right)$ (Michaelsen, Sebranek, \& Dickson, 2006; Rutherford et al., 2007). However, the protective effect of MAP is lost after opening the package, and remaining food kept for later consumption becomes quite risky for the development of L. monocytogenes (Buchanan \& Klawitter, 1990; Davies, 1997; Tsigarida, Skandamis, \& Nychas, 2000). In ActiHome packaging concept, edible films containing both soluble and bound antimicrobials are used for packaging or coating food products. Release of soluble antimicrobials provides antimicrobial effect at the food surface during transportation, storage, and marketing (Fig. 1A). The release of bound antimicrobials starts after activation of the film by the consumer immediately after purchasing the product at the market (Fig. 1B). Alternatively, the consumer could activate the packaging at home. This is reasonable when a protective packaging (MAP or VP) is opened at home shortly after purchase, and only part of the food is consumed (Fig. 1C). The first generation of ActiHome packaging materials developed by Boyac1 et al. (2016) from whey protein were quite successful to bind and immobilize positively charged LYS (pI at 11.4) onto negatively charged whey protein ( $\mathrm{pI}$ between 4.4 and 5.4) films in the $\mathrm{pH}$ range of smoked salmon (between $\mathrm{pH} 6.0$ and 6.3). However, due to the excessive negative charges of whey protein film matrix, these films bound and immobilized all incorporated LYS effectively. Thus, they lacked free LYS and were not active unless their $\mathrm{pH}$-triggered release mechanism was activated by the consumer by wetting the film with acidified lemon juice. In the present study, zein based composite packaging materials have been developed with both active and activate-at-home type properties. Zein is a protein obtained as a byproduct during corn processing by the bioethanol and oil industries (Selling, Woods, Sessa, \& Biswas, 2008; Xu, Reddy, \& Yang, 2007). It is a great candidate as an edible film-forming agent since it has excellent film-forming ability and good solubility in solvents like ethanol. Zein is a highly hydrophobic protein since it contains very limited number of hydrophilic amino acids that could form interactions with incorporated hydrophilic antimicrobial agents. Thus, protein-based antimicrobial agents like LYS remain mainly in free and soluble form when they are incorporated into zein films (Mecitoğlu et al., 2006; Güçbilmez, Yemenicioğlu \& Arslanoğlu, 2007). Therefore, composites of hydrophobic zein were formed by using suitable amounts of LPI or SPI that contain negatively charged groups ( $\mathrm{pI}$ value $\approx 4.5$ ) to bind part of the positively charged LYS. This strategy allows maintaining desired amounts of LYS in free soluble form while putting sufficient amounts of LYS in bound form within the LPI or SPI fraction in the film matrix. In this work, the presence of $\mathrm{LYS}_{\text {free }}$ and the good working of the proposed pH-triggered release mechanism for LYS $_{\text {bound }}$ in the composite films was proved by conducting extensive release tests in buffers and on selected food samples. Sliced beef, lamb meat, and smoked salmon were selected as food samples since they have been reported to pose risk of listeriosis (Dalgaard \& Jørgensen, 1998; Vermeulen, Devlieghere, De Loy-Hendrickx, \& Uyttendaele, 2011; Di Ciccio et al., 2012; D'Ostuni, Tristezza, , Giorgi, Rampino, Grieco, \& Perrotta, 2016; Smith et al., 2011). Antimicrobial activity of films originated from their LYS free $_{\text {and } \text { LYS }_{\text {bound }} \text { was }}$ also demonstrated on Listeria innocua. This work presented the second generation of ActiHome packaging materials that could be used both as a traditional antimicrobial film and as an advanced additional hurdle controlled by the consumer.

\section{Materials and methods}

\subsection{Materials}

Corn zein and LYS were obtained from Sigma Chem. Co. (St. Louis, MO, USA). Lentil (Cultivar Alidayı) used to produce LPI, was provided by the General Directorate of Agricultural Research in Ankara, Turkey. Soybean (non-GMO) used to produce SPI, and beef, lamb meat, and cold-smoked salmon were purchased from local supermarkets in İzmir, Turkey. The salmon sample was coldsmoked and vacuum packed, and it contains 3.5\% salt (product information). Fresh lamb and beef samples were from leg parts with the fascia layer on their surface. Bacterial strain of Listeria innocua (NRRL B-33314) used in antimicrobial tests was provided by United States Department of Agriculture, Microbial Genomics and Bioprocessing Research Unit, Peoria, Illinois (USA).

\subsection{Preparation of lentil and soy protein isolates}

LPI and SPI were extracted from dry lentil and soy beans. To remove lipids and phenolic compounds, lentil and soy seeds were first processed to acetone powder (AP) according to the method given by Arcan and Yemenicioğlu (2007). The APs were stored at $-18^{\circ} \mathrm{C}$ until they were used for protein extraction. Protein extraction was conducted by mixing $50 \mathrm{~g}$ of AP with $200 \mathrm{~mL}$ of distilled water, adjusting $\mathrm{pH}$ of the mixture to 9.0 with $1 \mathrm{~N} \mathrm{NaOH}$, and applying continuous stirring for $30 \mathrm{~min}$ at room temperature. To remove insoluble debris the extract was then centrifuged at $11,000 \times g$ for $30 \mathrm{~min}$ at $4{ }^{\circ} \mathrm{C}$. The supernatant containing solubilized protein was then separated, and its $\mathrm{pH}$ was adjusted to 4.5 with $1 \mathrm{~N}$ acetic acid solution to precipitate the proteins. The precipitated proteins were then collected by centrifugation at $11,000 \times \mathrm{g}$ for $30 \mathrm{~min}$ at $4{ }^{\circ} \mathrm{C}$, and they were dissolved again in $150 \mathrm{~mL}$ distilled water. The solubilized protein was then precipitated for the second time as described above by bringing extract $\mathrm{pH}$ 


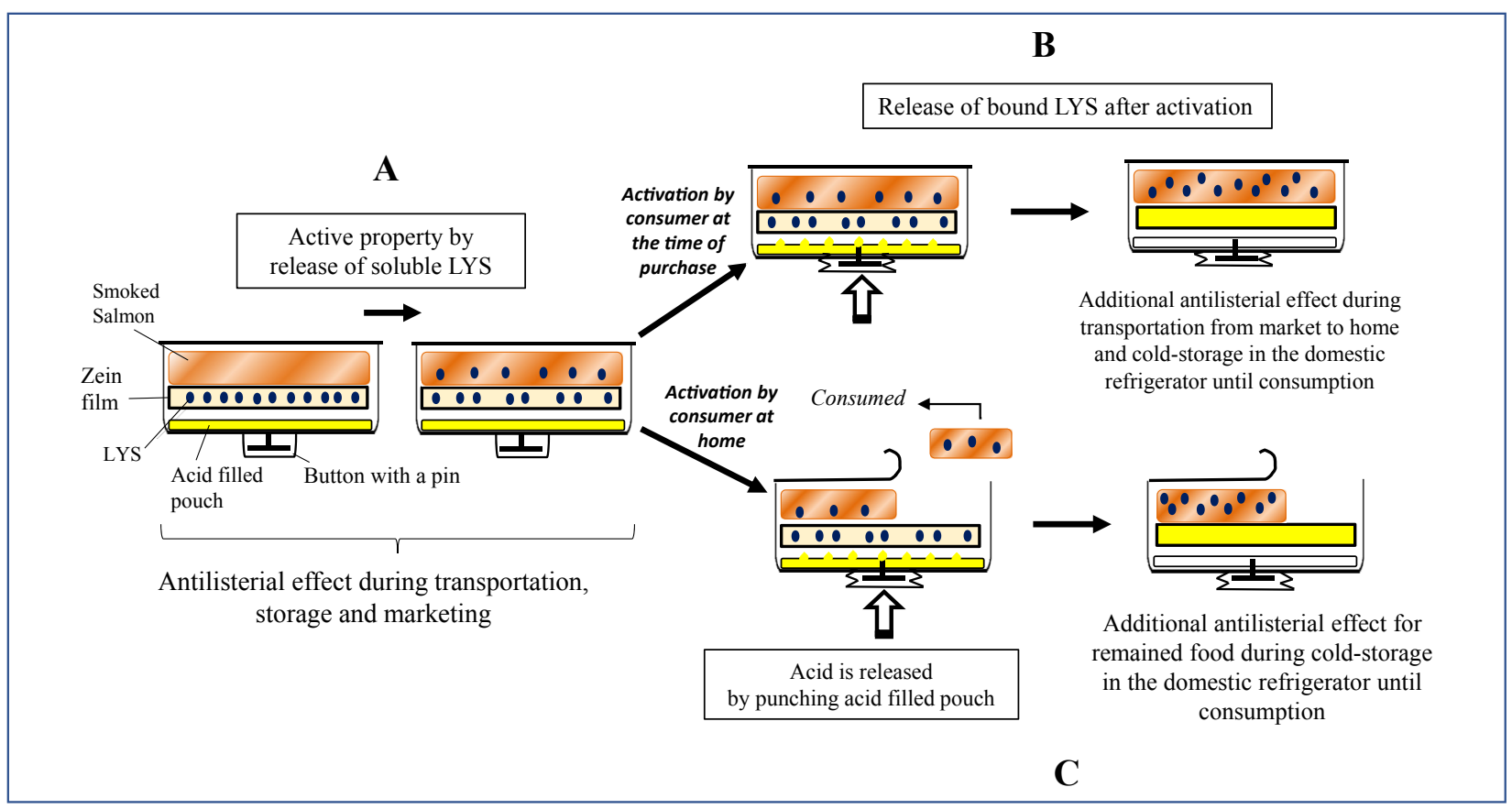

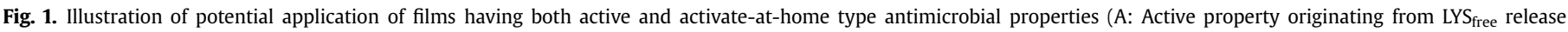

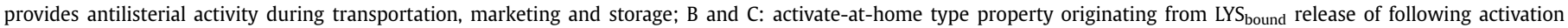
provides additional antilisterial activity based on different scenarios).

to 4.5 , collecting precipitated protein by centrifugation, and dissolving precipitate in distilled water. The $\mathrm{pH}$ of protein solution was then adjusted to 7.0 with $1 \mathrm{~N} \mathrm{NaOH}$, and the solution was lyophilized using a freeze dryer (Labconco, Kansas City, KS, USA). The lyophilized LPI and SPI were stored at $-18^{\circ} \mathrm{C}$ until they were used in film preparation.

\subsection{Preparation of films}

Zein-based composite films were prepared by modifying the standard zein film-making method described in Padgett, Han, and Dawson (1998). Briefly, $1.4 \mathrm{~g}$ zein was dissolved in $8.2 \mathrm{~mL}$ ethanol (96\%) by mixing slowly with a magnetic stirrer for $25 \mathrm{~min}$. Glycerol $(0.4 \mathrm{~mL})$ was added into the solution as plasticizer. The filmforming solution was then heated to boiling point and boiled for $5 \mathrm{~min}$ for denaturation of zein proteins. After cooling to room temperature, LPI or SPI at 130 or $390 \mathrm{mg} / \mathrm{g}$ of zein $(1.5$ or $4.5 \mathrm{mg} /$ $\mathrm{cm}^{2}$ of dried film), and LYS at $61 \mathrm{mg} / \mathrm{g}$ of zein $\left(0.7 \mathrm{mg} / \mathrm{cm}^{2}\right)$ were added into film-forming solution. The solution was then homogenized at $10,000 \mathrm{rpm}$ for $4 \mathrm{~min}$ using a homogenizer-disperser (Heidolph, Germany, rotor $\Phi=6.6 \mathrm{~mm}$ tip). After that, $4.3 \mathrm{~g}$ of film-forming solution was spread onto $8.5 \mathrm{~cm} \times 8.5 \mathrm{~cm}$ glass plates, previously cleaned with ethanol. Casted films were dried at $25^{\circ} \mathrm{C}$ for $20 \pm 2 \mathrm{~h}$.

\subsection{Determination of LYS activity}

LYS activity was measured spectrophotometrically at $660 \mathrm{~nm}$ by using Shimadzu (Model 2450, Japan) spectrophotometer equipped with a constant temperature cell holder at $30^{\circ} \mathrm{C}$. The reaction mixture was prepared by mixing $0.1 \mathrm{~mL}$ enzyme containing solution (incubated at $30^{\circ} \mathrm{C}$ for $1 \mathrm{~min}$ ) and $2.4 \mathrm{~mL}$ Micrococcus lysodeicticus suspension (at $30^{\circ} \mathrm{C}$ ) prepared in $0.05 \mathrm{M}$ Na-phosphate buffer at $\mathrm{pH}$ 7.0. The reaction mixture was mixed with a vortex, and the decrease in absorbance was monitored for $120 \mathrm{~s}$. Enzyme activity was calculated from the slope of the initial portion of absorbance vs. time curve, and it was expressed as Units released per $\mathrm{cm}^{2}$ of films. One Unit was defined as 0.001 change in absorbance in $1 \mathrm{~min}$. Average of three measurements was used in calculations. The activity of LYS solution determined by this method was $74548 \mathrm{U} / \mathrm{mg}$ of solution.

\subsection{Test of designed pH-triggered LYS release mechanism in buffers at different $\mathrm{pH}$}

The working of the designed pH-triggered release mechanism of films was tested in buffers at different $\mathrm{pH}$ values. This test shows

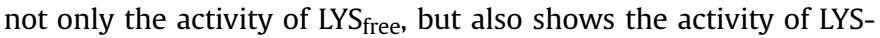
bound immobilized by charge-charge interactions. The release profiles of LYS at different $\mathrm{pH}$ was evaluated by incubation of films (zein, zein-LPI or zein-SPI films containing $0.7 \mathrm{mg} / \mathrm{cm}^{2}$ LYS) at $4{ }^{\circ} \mathrm{C}$ for $24 \mathrm{~h}$ in series of buffers $(50 \mathrm{~mL}$ of $\mathrm{Na}$-phosphate buffers at $\mathrm{pH}$ $7.3,6.3,5.3$ or Na-phosphate-HCl buffer at $\mathrm{pH} 4.3$ ) and monitoring their released LYS activities. The films cut into $16 \mathrm{~cm}^{2}(4 \mathrm{~cm} \times 4 \mathrm{~cm})$ pieces were sequentially kept firstly in buffer at $\mathrm{pH} 7.3$ for $24 \mathrm{~h}$, secondly in buffer at pH 6.3 for $24 \mathrm{~h}$, thirdly in buffer at pH 5.3 for $24 \mathrm{~h}$, and lastly in buffer at $\mathrm{pH} 4.3$ for $24 \mathrm{~h}$. The LYS activity was measured as described in section 2.4 by taking $0.3 \mathrm{~mL}$ samples periodically and conducting three measurements $(3 \times 0.1 \mathrm{~mL})$ at each incubation time. Calculations were corrected by considering activities removed from the aqueous media during sampling. The total activity of released LYS from a film was calculated by determining the sum of each activity at $\mathrm{pH} 7.3,6.3,5.3$ and 4.3 within $96 \mathrm{~h}(4 \times 24 \mathrm{~h})$. The total activity of released LYS from control zein film was accepted as $100 \%$. All other activities were reported as percentage in respect to total activity of released LYS from control zein film. The results were expressed on histograms by plotting released activity (\%) from each type of film within $24 \mathrm{~h}$ at different buffers. 


\subsection{Test of designed $p H$-triggered LYS release mechanism in different foods}

The $\mathrm{pH}$-triggered release mechanism of films was also tested on slices of beef, lamb meat, and cold smoked salmon. Briefly, zein, zein-LPI $\left(4.5 \mathrm{mg} / \mathrm{cm}^{2}\right.$ LPI) or zein-SPI $\left(4.5 \mathrm{mg} / \mathrm{cm}^{2} \mathrm{SPI}\right)$ films $(2 \mathrm{~cm} \times 2 \mathrm{~cm})$ containing $0.7 \mathrm{mg} / \mathrm{cm}^{2}$ LYS were placed on one side of the food slices (4-4.5 $\mathrm{g}$ of beef and lamb meat, $1.4-1.5 \mathrm{~g}$ of salmon). The films on beef and lamb meats were in contact with the fascia/epimysium layer of the muscle. The coated samples were then wrapped with a plastic stretch film, and then with an aluminum foil to increase film-food contact. The samples were then cold-stored at $4{ }^{\circ} \mathrm{C}$ for 2 days to cause release of LYS $S_{\text {free }}$ in films. At the end of 2 days, the packs were opened, and $0.2 \mathrm{~mL}$ of $10 \%(\mathrm{v} / \mathrm{v})$ lactic acid solution was pipetted onto surfaces of the films to activate films. The acidification aimed to drop film $\mathrm{pH} \leq 4.5$, a suitable $\mathrm{pH}$ to initiate release of bound LYS in the film matrix. The coated samples were then packed again (with plastic stretch films and aluminum foil) and cold-stored at $4{ }^{\circ} \mathrm{C}$ for 5 days (total 7 days) to monitor release of LYS by acidification. A control of each film group was also used in packaging of different food, but these groups were cold-stored without acidification. During cold-storage, some packs were taken every $24 \mathrm{~h}$, and assayed for LYS activity after enzyme extraction. For extraction of LYS, the films were first removed from the food surface. Food sample was then homogenized for $1 \mathrm{~min}$ in $10 \mathrm{~mL}$ of buffer (0.1 M PBS at pH 6.0) using a blender (Waring with $30 \mathrm{~mL}$ jar, USA, Model: 7011HS). The homogenate was then clarified by centrifugation at $11,000 \times \mathrm{g}$ for $10 \mathrm{~min}$ at $4{ }^{\circ} \mathrm{C}$. LYS activity was determined by using $0.1 \mathrm{~mL}$ of supernatant in triplicate $(3 \times 0.1 \mathrm{~mL})$ as described in section 2.4. The activity of LYS released into sample was then calculated and expressed as Units released per $\mathrm{cm}^{2}$ of the films.

\subsection{Antimicrobial activity of films}

The antimicrobial activity of films was determined by the modification of the classical zone-inhibition assay, using Listeria innocua (NRRL B-33314) as test microorganism. The inoculum was prepared in peptone water $(0.1 \%)$, using a $24 \mathrm{~h}$ culture of $L$. innocua growth on nutrient agar incubated at $37^{\circ} \mathrm{C}$. The cell concentration was set to $1.0 \mathrm{McFarland}$ unit $\left(3 \times 10^{8} \mathrm{CFU} / \mathrm{mL}\right)$. Sixteen discs from each film were cut by a sterile cork-borer, and the discs $(13 \mathrm{~mm}$ in diameter) were placed on agar plates inoculated by L. innocua. Petri dishes were incubated at $37^{\circ} \mathrm{C}$ for $24 \mathrm{~h}$, and the area of the clear zones formed around the discs was measured and calculated using a digital micrometer. These results originated from $\mathrm{LYS}_{\text {free }}$ in the films. After the measurement of zones, the discs on the agar plates were carefully removed with a sterile pincer and transferred to surfaces of newly inoculated fresh agar plates. Each type of film discs were then separated into two groups. One of the two disc groups was then acidified to activate $\mathrm{pH}$-triggered LYS release by pipetting $10 \mu \mathrm{L}$ of $0.5 \mathrm{M}$ sterile Na-acetate buffer at $\mathrm{pH} 4.3$ onto film surfaces. The other groups were monitored as control, and they were not acidified. All the plates were then incubated at $37^{\circ} \mathrm{C}$ for $24 \mathrm{~h}$, and the area of the clear zones formed around transferred discs was calculated after measuring the zone diameters using a digital micrometer. The results from acidified films originated mainly from residual soluble LYS $_{\text {free }}$ left in the films following first

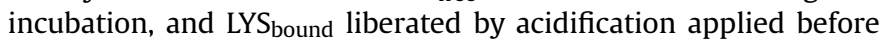
initiation of second incubation.

\subsection{Mechanical and morphological properties of films}

Mechanical properties of films were evaluated by measuring tensile strength, elongation at break and elastic modulus of films using the TA.XT-2 texture analyzer (Stable Microsystems, Godalming, UK) according to ASTM Standard Method D-882-02 (ASTM, 2002). Films were conditioned in an environmental chamber at $25{ }^{\circ} \mathrm{C}$ and $50 \% \mathrm{RH}$ for $24 \mathrm{~h}$. For mechanical tests, films were cut into $8 \mathrm{~mm}$-wide and $80 \mathrm{~mm}$-length strips. The initial grip distance was $50 \mathrm{~mm}$, and the crosshead speed was $50 \mathrm{~mm} / \mathrm{min}$. At least seven replicates of each film were tested. Tensile properties were calculated from the plot of stress versus strain.

The film morphologies were determined by obtaining their cross-sectional photographs using a scanning electron microscope (SEM) (Philips XL 30S FEG, FEI Company, Eindhoven, Netherlands). Film strips with $8 \mathrm{~mm}$ width were first broken in liquid nitrogen, and then they were coated by gold palladium for $1 \mathrm{~min}$ in a Magnetron Sputter Coating Instrument (Emitech K550X, Quorum Technologies Inc., UK) before photographed in the SEM. The average thicknesses of films were measured from the $5000 \times$ magnified micrographs. The film thicknesses were measured from SEM cross-sectional views by using Scandium software (Olympus Soft Imaging Solutions GmbH, Münster, Germany).

\subsection{Statistical analysis}

Statistical analysis was performed by using MINITAB ${ }^{\circledR}$ release 14 (Minitab Inc., State College, Pa., U.S.A.). Data were analyzed by using one-way analysis of variance (ANOVA). Significance was accepted at $\mathrm{p}<0.05$.

\section{Results and discussion}

\subsection{Test of designed pH-triggered release mechanism in different buffers}

LYS release profiles of zein, zein-LPI and zein-SPI films in different buffers are presented in Figs. 2 and 3. Tests conducted at $\mathrm{pH} 7.3$ for $24 \mathrm{~h}$ clearly showed the release of LYS free from different films. Due to the limited number of negatively charged groups in zein (Shukla \& Cheryan, 2001; Argos, Pedersen, Marks, \& Larkins, 1982), 80 to $90 \%$ of total activity for LYS released from zein control films was due to LYS free released from films at pH 7.3. It is clear that the addition of LPI or SPI at $1.5 \mathrm{mg} / \mathrm{cm}^{2}$ did not considerably affect the activity of LYS $_{\text {free }}$ released from zein-LPI and zein-SPI films at pH 7.3. In contrast, the increase of LPI and SPI from 1.5 to $4.5 \mathrm{mg} / \mathrm{cm}^{2}$ caused almost $48 \%$ and $58 \%$ lower $\mathrm{LYS}_{\text {free }}$ release from zein-LPI and zein-SPI films than related zein controls at $\mathrm{pH} 7.3$,

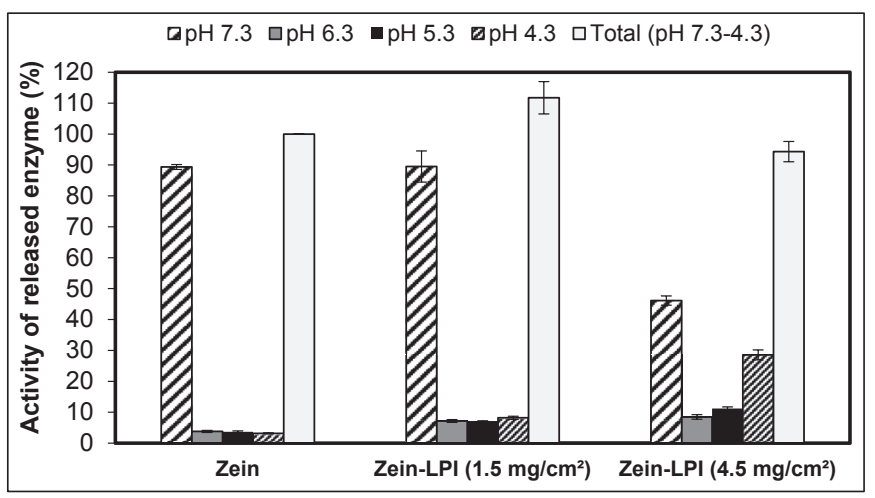

Fig. 2. Activities of LYS released from zein control (\#1) and zein-LPI (1.5 or $4.5 \mathrm{mg}$ $\mathrm{cm}^{2}$ ) films after sequential incubation of films for $24 \mathrm{~h}$ at each of buffers at $\mathrm{pH} 7.3,6.3$, 5.3 and 4.3 [Note-1: total incubation period for a single film $(4 \times 24 \mathrm{~h})$ was $96 \mathrm{~h}$; note2: Total activity released from the zein control film at different $\mathrm{pH}$ within $96 \mathrm{~h}$ was accepted as $100 \%$. All other activities were reported in respect to total activity released from zein control film). 


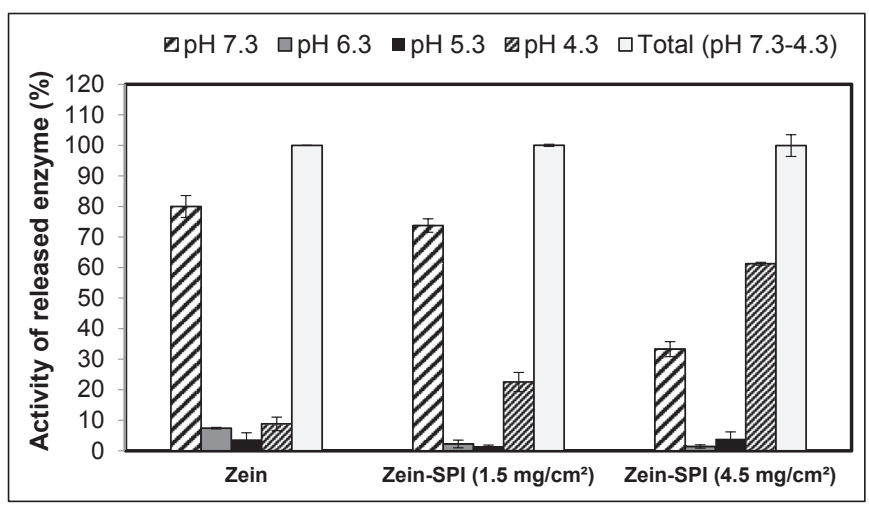

Fig. 3. Activities of LYS released from zein control (\#2) and zein-SPI (1.5 or $4.5 \mathrm{mg}$ / $\mathrm{cm}^{2}$ ) films after sequential incubation of films for $24 \mathrm{~h}$ at each of buffers at $\mathrm{pH} 7.3,6.3$, 5.3 and 4.3 [Note-1: total incubation period for a single film $(4 \times 24 \mathrm{~h})$ was $96 \mathrm{~h}$; note2: Total activity released from the zein control film at different $\mathrm{pH}$ within $96 \mathrm{~h}$ was accepted as $100 \%$. All other activities were reported in respect to total activity released from zein control film).

respectively. These results suggested that the negative charge formed at $\mathrm{pH} 7.3$ in composite films containing SPI or LPI at $4.5 \mathrm{mg} /$ $\mathrm{cm}^{2}$ caused binding of a significant portion of positively charged LYS. Moreover, it is important to report that the sum of activities for LYS released from zein-LPI film at pH 6.3 and 5.3 was almost 5-fold higher than that released from zein-SPI film at the same $\mathrm{pH}$ values. The recent study of Aydemir and Yemenicioğlu (2013) showed that $\mathrm{pI}$ for lentil protein fractions varied in a wide range between $\mathrm{pH} 4.5$ and 6.5. Thus, it seemed that the reduced negative charge intensity of some lentil protein fractions in the zein-LPI film matrix at $\mathrm{pH} 6.3$ and 5.3 caused the release of part of the LYS $_{\text {bound }}$ from zein-LPI films. On the other hand, the transfer of zein-SPI and zein-LPI films from buffer at $\mathrm{pH} 5.3$ to buffer at $\mathrm{pH} 4.3$ had initiated release of considerable amounts of LYS from films. It was clear that the reduced $\mathrm{pH}$ caused loss of negative charges on the majority of LPI and SPI fractions in the composite film matrix, and this liberated a significant portion of $\mathrm{LYS}_{\text {bound }}$ from the films. Activity for released LYS $_{\text {bound }}$ at pH 4.3 from composite films with $4.5 \mathrm{mg} / \mathrm{cm}^{2}$ LPI and SPI was almost $30 \%$ and $61 \%$ of total activity for released LYS from these films at different $\mathrm{pH}$ values (at $\mathrm{pH} 7.3,6.3,5.3$ and 4.3 within $96 \mathrm{~h}$ ), respectively. The higher LYS $_{\text {bound }}$ of zein-SPI films than zeinLPI films at pH 4.3 suggested that the SPI is particularly rich in protein fractions with low pI value ( $<$ pI 5.3). Thus, LYS $_{\text {bound }}$ in zeinSPI films released as a bulky fraction only when $\mathrm{pH}$ dropped from 5.3 to 4.3 , slightly below their reported pI of 4.9 (Okubo, Waldrop, Iacobucci, \& Myers, 1975). In contrast, LPI contains protein fractions with $\mathrm{pI}$ between 4.3 and 6.3. Thus, LYS $S_{\text {bound }}$ in zein-LPI films released gradually as $\mathrm{pH}$ dropped from 7.3 to 4.3 . The results of release tests also showed that the inherently charged groups in zein control films also had a limited LYS binding capacity. The sum of activities for LYS released from zein control films at $\mathrm{pH} 5.3$ and 4.3, ( $\mathrm{pH}$ values below pI of zein, 6.2), changed from 7 to $13 \%$ of the total activity for LYS released from these films at different $\mathrm{pH}$ values (at $\mathrm{pH} 7.3,6.3,5.3$ and 4.3 within $96 \mathrm{~h}$ ).

The total activity of LYS released into buffers at different $\mathrm{pH}$ values within $96 \mathrm{~h}$ also helped calculation of yield for films based on released enzyme activity (Yield of films for LYS activity $=$ (Total activity of LYS released from films/Activity of LYS incorporated into films) $x$ 100). The average LYS activity yield for different control zein films $(n=2)$ was $91 \%$. On the other hand, LYS activity yields for composite films with 1.5 and $4.5 \mathrm{mg} / \mathrm{cm}^{2}$ LPI were $105 \%$ and $89 \%$, respectively. The yield over $100 \%$ for the composite film with LPI at $1.5 \mathrm{mg} / \mathrm{cm}^{2}$ suggested some slight heterogeneity in LYS distribution of this film (a $4 \mathrm{~cm} \times 4 \mathrm{~cm}$ piece from a $8.5 \mathrm{~cm} \times 8.5 \mathrm{~cm}$ cast film). The higher yield of this composite film than the others also suggested the reduced entrapment of LYS in this film. It seemed that the distribution of hydrophilic LPI molecules within composite film matrix reduced the fraction of LYS physically entrapped within the hydrophobic zein clusters. In contrast, similar activity yields of composite film with $4.5 \mathrm{mg} / \mathrm{cm}^{2}$ LPI and control film suggested some LYS entrapment by aggregated LPI and/or LPI-zein complexes. On the other hand, LYS activity yields of composite films with 1.5 and $4.5 \mathrm{mg} / \mathrm{cm}^{2}$ SPI were $77 \%$ and $74 \%$, respectively. These results suggested significantly higher capacity of SPI than that of LPI to cause physical entrapment of LYS within zein film matrix.

\subsection{Test of designed $\mathrm{pH}$-triggered release mechanism in different packed foods}

\subsubsection{LYS release profiles before acidification of films $\left(24^{\text {th }}\right.$ and $48^{\text {th }}$ $h$ of cold storage)}

Results of release tests conducted with slices of lamb meat, beef, and smoked salmon packed with developed films, and cold stored at $4{ }^{\circ} \mathrm{C}$ are presented in Fig. 4 . The release of $\mathrm{LYS}_{\text {free }}$ from different films onto lamb meat before activation conducted by acidification of films was seen in Fig. 4A and C. The activity of LYS released onto lamb meat from zein films is almost 3 and 2.4-fold higher than those released from zein-LPI and zein-SPI films at the end of $48 \mathrm{~h}$, respectively. This result was expected since previous release tests conducted in buffers proved the lower amounts of LYS $_{\text {free }}$ in composite films than in zein control film.

The activity of LYS released onto beef samples from zein films at the end of $48 \mathrm{~h}$ is also almost 3.3 and 3.5-fold higher than that released from zein-LPI and zein-SPI films, respectively. Initial release profiles of LYS from zein films onto beef and lamb samples were similar (Fig. 4D). Zein-LPI films also showed similar initial LYS release profiles for beef and lamb samples in the first $48 \mathrm{~h}$ (Fig. 4E). However, it is important to note that zein and zein-LPI films showed almost $33 \%$ and $28 \%$ higher LYS activity on beef than that on lamb meat within $48 \mathrm{~h}$. On the other hand, the initial LYS release profiles of zein-SPI films followed a different profile in lamb and beef samples (Fig. 4F). Release of LYS from zein-SPI films onto lamb meat occurred rapidly in the first $24 \mathrm{~h}$, but instability of enzyme in lamb meat caused a moderate drop (-20\%) in its LYS activity at $48 \mathrm{~h}$. In contrast, LYS release from zein-SPI films onto beef occurred slowly, but it increased continuously and reached almost the same activity with lamb meat at the end of $48 \mathrm{~h}$.

Activity measurements suggested that all films released much more LYS on smoked salmon than that on lamb meat and beef within shorter time periods (Fig. 4G and I). For example, LYS activities measured for smoked salmon packed with zein, zein-LPI and zein-SPI films within $24 \mathrm{~h}$ were 1.5-6.4-fold higher than those of beef and lamb meat. It seemed that the fascia/epimysium layer at the surfaces of lamb meat and beef acted as a barrier for the film swelling, and this slowed down the diffusion of LYS from films onto these samples. In contrast, films placed on salmon slices might have swelled rapidly since these samples lacked such a continuous protective layer. It is also interesting to report that zein and zein-LPI films released almost the same amount of LYS onto the salmon surface at the end of $24 \mathrm{~h}$. This result suggested that the release of LYS $_{\text {bound }}$ initiated (triggered) in zein-LPI films before acidification. It seemed that the salt used in salmon curing $(\approx 4 \%(\mathrm{w} / \mathrm{w}))$ caused the destabilization of attractive charge-charge interactions between LYS $_{\text {bound }}$ and zein-LPI film matrix, and this caused release of some enzyme from films. The destabilization of electrostatic interactions between a protein and a charged matrix in presence of salts is a well-known scientific truth, and this is frequently exploited to extract enzyme bound by electrostatic interactions in tissues 


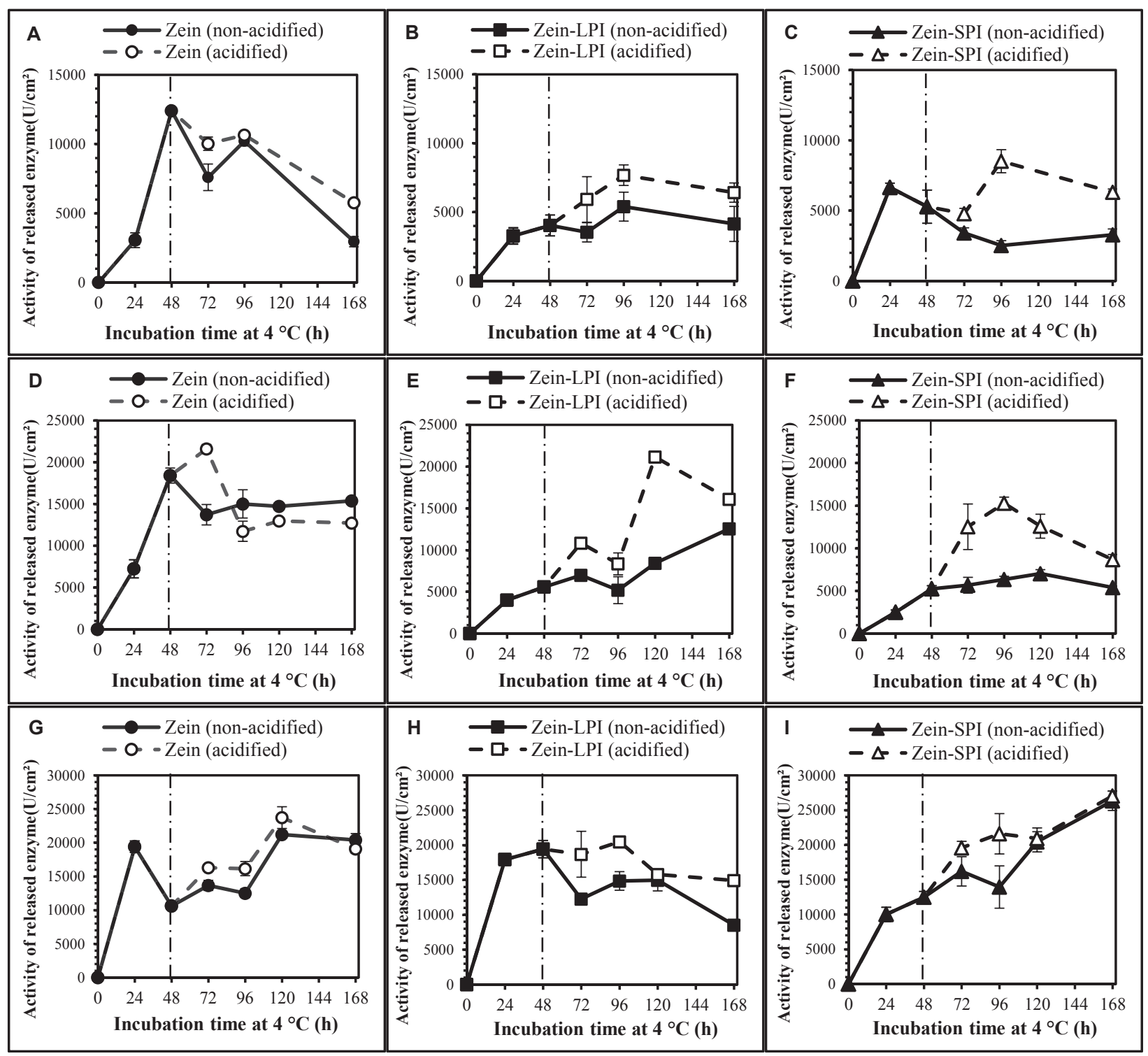

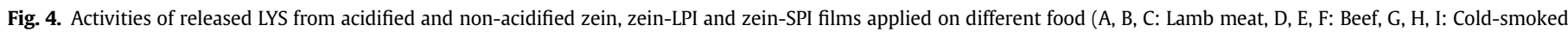

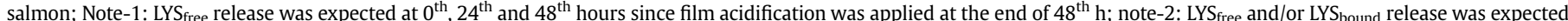

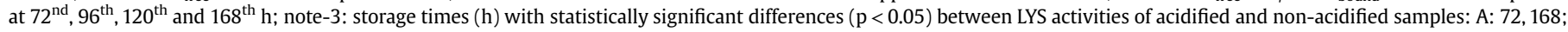
B: 96, 168; C: 72, 96, 168; D: 72, 96, 120, 168; E: 72, 120, 168; F: 72, 96, 120, 168; G: 72, 96; H: 72, 96, 168; I: 96).

(Yemenicioğlu \& Cemeroğlu, 1999). The same principle is also used to elute enzyme and protein from ion-exchange columns during purification (Yemenicioğlu, Özkan, \& Cemeroğlu, 1998). In contrast, a considerable solubilization of LYS bound was not observed in smoked salmon packed with zein-SPI films. Thus, the salmon samples packed with zein-SPI films showed 1.8-1.9-fold lower LYS activity than those packed with zein and zein-LPI films at the end of $24 \mathrm{~h}$. This could be related to the more powerful (extensive) attractive charge-charge interactions of LYS with zein-SPI film matrix than zein-LPI film matrix. In fact, the findings obtained with release tests conducted in buffer at different $\mathrm{pH}$ supported that the LYS attached more tightly on zein-SPI films than on zein-LPI films (see section 3.1). At $48^{\text {th }} \mathrm{h}$ of cold storage, activities of LYS released from zein-LPI and zein-SPI films onto smoked salmon increased gradually. In contrast, activity of LYS released from zein film onto smoked salmon showed a dramatic reduction at $48 \mathrm{~h}$ of coldstorage (almost $-45 \%$ ). It seemed that release of LYS $_{\text {free }}$ from zein films onto smoked salmon ceased after $24 \mathrm{~h}$. Thus, the activity loss due to destabilizing reactions with smoked salmon components could not be balanced with fresh enzyme released gradually from zein films.

\subsubsection{LYS release profiles after acidification of films $\left(72^{\text {nd }}\right.$ to $168^{\text {th }} h$ of cold storage)}

The control zein and composite zein films placed on surfaces of samples were acidified at the end of $48^{\text {th }} \mathrm{h}$ to simulate their activation. Samples were then further cold stored for $120 \mathrm{~h}$, and they were monitored for their LYS activities. At this stage, the release test become highly complex since there are multiple dependent variables [LYS release rate, loss in LYS activity due to instability, and

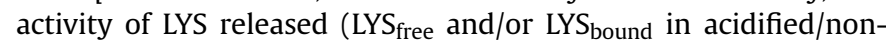
acidified samples)] against the independent variables (storage time and acidification). Lamb meat samples packed with nonacidified and acidified zein films showed a sharp reduction in 
their LYS activities after $48^{\text {th }} \mathrm{h}$ of cold storage. However, LYS activity in lamb meat packed with non-acidified zein films showed much more dramatic reduction (-76\%) than those packed with acidified zein films $(-54 \%)$ at the end of $168 \mathrm{~h}$. These findings clearly showed the high instability of LYS in lamb meat. Moreover, the results also suggested that the pH-triggered release of LYS bound by inherently charged groups in zein control film might improve LYS activities of the product. On the other hand, the activation of zein-LPI and zeinSPI films by acidification at the end of $48^{\text {th }} \mathrm{h}$ caused a gradual increase (started at $72^{\text {nd }}$ and peaked at $96^{\text {th }} \mathrm{h}$ ) and a sharp increase (at $96^{\text {th }} \mathrm{h}$ ) in LYS activities of packed lamb meat, respectively. At similar acidification conditions, 24 h earlier initiation of LYS activity increase in lamb samples coated with zein-LPI films suggested a better response of $\mathrm{pH}$-triggering mechanism in these films than that in zein-SPI films. LYS activities of lamb meats packed with both acidified composite films showed a slight reduction in LYS activity after $96 \mathrm{~h}$. However, it is important to report that LYS activities of lamb samples packed with acidified composite films at the end of $168^{\text {th }} \mathrm{h}$ of cold storage were almost 2-fold higher than that for lamb meat packed with non-acidified control zein films. Thus, it appeared that the acidification to exploit $\mathrm{pH}$-controlled release properties of composite films was a more beneficial delivery strategy than classical active packaging conducted with nonacidified zein films. On the other hand, it should be reported that the activity of LYS released onto lamb meat from acidified composite films at $168^{\text {th }} \mathrm{h}$ were not considerably higher (almost $10 \%$ ) than that from acidified zein films. Thus, it is clear that the composite films should be prepared with higher levels of LYS and LPI or SPI to increase amounts of their LYS free $_{\text {and }}$ LYS $_{\text {bound }}$ fractions.

On the other hand, results for LYS activity measurements with cold-stored beef samples after acidification followed a slightly different pattern than those of lamb samples. First of all, the pHtriggered release mechanism in acidified zein control films showed its benefit only at the $72^{\text {nd }} \mathrm{h}$ of cold storage by causing a peak LYS activity at $21600 \mathrm{U} / \mathrm{cm}^{2}$. In contrast, the acidified zein-LPI films caused a gradual increase in LYS activities of beef samples. It is important to note that in beef packed with acidified zein-LPI films a peak LYS activity (almost $21000 \mathrm{U} / \mathrm{cm}^{2}$ ) was reached at the $120^{\text {th }} \mathrm{h}$, two days later than that observed for beef samples packed with acidified zein films. This result showed the possibility of achieving a sustained LYS release by using $\mathrm{pH}$-triggered release mechanism in beef packed with zein-LPI films. The $\mathrm{pH}$-triggered release mechanism also worked on beef samples packed with zein-SPI composite films. However, the release of LYS from acidified zein-SPI films onto beef samples made a peak at the $96^{\text {th }} \mathrm{h}$. Moreover, the maximal activity reached for beef samples packed with acidified zein-SPI films was almost 30\% lower than those reached for beef samples packed with acidified zein and acidified zein-LPI films. This result showed that the response of $\mathrm{pH}$-triggered release mechanism of zein-LPI film on the beef surface is better than that in zein-SPI film. On the other hand, the overall results clearly showed that the maximum LYS activities and final LYS activity levels reached in packed beef were higher than those of lamb meat. It seemed that differences in biochemical status of lamb meat and beef affected the stability of LYS. The proteases (e.g. calpains, cathepsins, calpastatins and Ca-dependent proteases) play a central role in biochemical changes in meat. However, the activity and stability of proteases as well as level of protease regulating inhibitors could be variable in meats of lamb and cattle (Morton, Bickerstaffe, Kent, Dransfield, \& Keeley, 1999; Ouali \& Talmant, 1990; Koohmaraie, Whipple, Kretchmar, Crouse, Mersmann, 1990).

Release of LYS from acidified and non-acidified zein control films on smoked salmon followed a quite similar profile and showed a gradual increase up to $120^{\text {th }} \mathrm{h}$ of cold storage. Salmon samples packed with acidified zein films showed significantly higher LYS activities (1.2-1.3-fold) than those packed with nonacidified zein films at $72^{\text {nd }}$ and $96^{\text {th }} \mathrm{h}$ of storage $(\mathrm{p}<0.05)$. On the other hand, some more significant differences were observed between LYS activities of salmon samples packed with acidified and non-acidified zein-LPI films. The activities of LYS released on salmon packed with acidified zein-LPI films were significantly higher (1.4-1.8-fold) than those of salmon packed with nonacidified zein-LPI films at the $72^{\text {nd }}, 96^{\text {th }}$ and $168^{\text {th }} \mathrm{h}$ of cold storage $(\mathrm{p}<0.05)$. However, it should also be reported that significant reductions were observed in LYS activities of salmons packed with acidified $(-23 \%)$ and non-acidified $(-43 \%)$ zein-LPI films after $96^{\text {th }}$ and $120^{\text {th }} \mathrm{h}$ of cold storage, respectively. This result suggested the exhaustion of LYS reservoirs in zein-LPI films at the later periods of cold storage. In contrast, the LYS activity of acidified and nonacidified zein-SPI films increased continuously up to the $168^{\text {th }} \mathrm{h}$ of cold storage. At the $96^{\text {th }} \mathrm{h}$ of cold storage, salmon packed with acidified zein-SPI films showed significantly higher (1.6-fold) LYS activity than that packed with non-acidified zein-SPI films $(\mathrm{p}<0.05)$. However, LYS release profiles of acidified and nonacidified zein-SPI films applied on salmon samples were quite similar at the $120^{\text {th }}$ and $168^{\text {th }} \mathrm{h}$ of cold storage $(\mathrm{p}>0.05)$. These findings suggested that at the later stages of cold-storage the LYSbound in non-acidified zein-SPI films liberated spontaneously from SPI fraction in the film matrix and released onto smoked salmon. Thus, it is once more proved that the cured products that contain salts which are capable to destabilize ionic interactions between LYS and film matrix might interfere with the $\mathrm{pH}$-controlled release system. It is important to note that the non-acidified zein-LPI film suffered from spontaneous release of LYS bound at the beginning of storage (within the first $48 \mathrm{~h}$ ) while the same problem was observed in zein-SPI films at the later stages of cold storage $(\geq 120 \mathrm{~h}$ ). Thus, it is clear that the zein-SPI film is a better option than zein-LPI film when target food is rich in salts. Further studies are needed to optimize SPI content of films for cured samples and test alternative proteins that could form more resistant ionic interactions with LYS.

\subsection{Antimicrobial activity of films}

The antimicrobial activity of developed zein, zein-LPI, and zeinSPI films were tested against non-pathogenic Listeria innocua which is used as an indicator for the critical pathogenic bacteria L. monocytogenes (Francis \& Bernie, 1997). The zone inhibition tests were conducted first with non-acidified films to prove the active properties of films originated from LYS $_{\text {free }}$ (Table 1$)$. The zones determined for non-acidified zein films within $24 \mathrm{~h}$ incubation period were almost 2-fold larger than those for non-acidified zeinLPI and zein-SPI films that gave quite similar zone areas ( $p>0.05)$. This result was expected since the majority of the LYS in zein films was free while composite films obtained with $4.5 \mathrm{mg} / \mathrm{cm}^{2}$ SPI or LPI

\section{Table 1}

Antimicrobial activity of acidified and non-acidified zein, zein-LPI and zein-SPI films on L. innocua.

\begin{tabular}{|c|c|c|c|c|c|}
\hline \multirow{2}{*}{\multicolumn{3}{|c|}{$\begin{array}{l}\text { Incorporated } \\
\text { concentration } \\
\left(\mathrm{mg} / \mathrm{cm}^{2}\right)\end{array}$}} & \multicolumn{3}{|c|}{ Zone areas of the films $\left(\mathrm{mm}^{2}\right)$} \\
\hline & & & \multirow{2}{*}{$\frac{\text { (first } 24 \text { h-incubation) }}{\text { non-acidified films }}$} & \multicolumn{2}{|c|}{ (second 24 h-incubation) } \\
\hline LYS & LPI & SPI & & non-acidified films & acidified films \\
\hline- & - & - & No clear zone & No clear zone & No clear zone \\
\hline 0.7 & - & - & $102.8 \pm 9.1^{\mathrm{a}}$ & $31.0 \pm 7.0^{\mathrm{a}}$ & $24.6 \pm 2.6^{\mathrm{b}}$ \\
\hline 0.7 & 4.5 & - & $55.2 \pm 3.2^{\mathrm{b}}$ & $48.8 \pm 2.7^{\mathrm{a}}$ & $67.5 \pm 7.9^{\mathrm{a}}$ \\
\hline 0.7 & - & 4.5 & $47.6 \pm 1.6^{\mathrm{b}}$ & $46.0 \pm 1.9^{\mathrm{a}}$ & $65.1 \pm 8.7^{\mathrm{a}}$ \\
\hline
\end{tabular}

a-b different letter at each column indicate statistically significant changes at $\mathrm{p}<0.05$. 
contained lower activities of $\mathrm{LYS}_{\text {free }}$ at slightly acidic to neutral $\mathrm{pH}$ values (between pH 5.3 and 7.3). At the end of first $24 \mathrm{~h}$ incubation on agars, the films were aseptically transferred onto new agars inoculated with fresh $L$. innocua culture. Half of the films were acidified while the remaining films were not acidified. The formation of clear zones in non-acidified zein and non-acidified composite films at the end of second $24 \mathrm{~h}$ incubation period in fresh medium clearly showed the presence of considerable amounts of

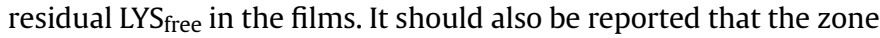
areas of non-acidified zein and composite films at the end of second incubation period were not significantly different from each other ( $p>0.05)$. However, it is important to report that the zone areas of acidified zein-SPI and zein-LPI composite films at the end of second incubation were almost 1.4-fold higher than those of the nonacidified composite films. The acidified composite control films lacking LYS did not form clear zones. Thus, these results clearly showed the antimicrobial activity of LYS bound $_{\text {liberated from films }}$ by activation of the designed $\mathrm{pH}$-triggered release mechanism. The acidified composite films also had 2.1 and 2.7-fold higher antimicrobial activity than non-acidified and acidified zein control films, respectively. These results suggested better antimicrobial potential of activated LYS containing composite films than standard LYS containing zein films. In contrast, slightly lower antimicrobial activity of acidified zein films than non-acidified zein films at the second incubation period suggested the lack of any considerable antimicrobial potential for LYS bound in these films.

\subsection{Mechanical and morphological properties of films}

Mechanical properties of zein and composite films were evaluated by determining their tensile strength, elongation at break and Young's modulus values (Table 2). Although the incorporation of LYS into zein films caused a significant reduction in their Young's modulus, it caused no significant changes in tensile strength and elongation of films ( $p>0.05$ ). The SEM cross-section photos (Fig. 5A and B) of zein control and LYS containing zein films did not also indicate any considerable changes in classical highly porous nature of zein films (Arcan, Boyacı, \& Yemenicioğlu, 2017). These results suggested the lack of any considerable interaction and networking between hydrophobic zein film matrix and hydrophilic LYS. The incorporation of $4.5 \mathrm{mg} / \mathrm{cm}^{2}$ LPI or SPI into zein films with LYS did not cause a significant change in tensile strength of LYS containing zein films ( $\mathrm{p}<0.05$ ). However, addition of LPI and SPI at $4.5 \mathrm{mg} / \mathrm{cm}^{2}$ caused significant increases and reductions in elongation and Young's modulus values of composite films $(p<0.05)$. The SEM pictures of film cross-sections suggested the change of highly porous nature of zein films to a dense one by incorporation of SPI and LPI into films (Fig. 5C and D). Such dramatic morphological changes in composite films suggested interaction of hydrophobic zein with LPI and SPI that are amphiphilic proteins with good surface active properties (Aydemir \& Yemenicioğlu, 2013). The interactions could change the typical orientation of zein molecules in film that has been defined as a meshwork which is composed of doughnut structures formed by asymmetric rods joined to each other (Guo, Liu, An, Li, \& Hu, 2005). The interaction of zein with LPI or SPI could also reduce the hydrophobic interactions among asymmetric zein rods. Thus, the porous nature of films has turned to denser one. These results suggested that the zein based composites could be an opportunity to reduce the classical brittleness problem of zein films.

During food applications both control zein film and composite films showed good affinity on food surfaces and maintained their integrity if they are not disturbed (see supplementary file 1). However, at the later stages of cold-storage (e.g. at $96^{\text {th }} \mathrm{h}$ for beef) a gentle attempt to unpeel zein control films from food surfaces caused local disintegration in acidified and nonacidified films (see supplementary file 2). Superficial local cracks also appeared in zeinLPI and zein-SPI films, but these films (acidified or non-acidified) peeled off from food surfaces without disintegration. These results suggested a certain improvement in mechanical properties of composite films. However, more detailed studies are needed to determine long-term effects of SPI and LPI on mechanical and morphological properties of zein films during processing and storage.

\section{Conclusions}

The results of this work clearly showed the possibility of designing antimicrobial composite films with active and consumercontrolled activate-at-home-type antimicrobial properties. The release tests conducted with zein-SPI and zein-LPI films in different buffers and in different foods clearly showed the presence of free and bound LYS fractions in the composite films. The timing of release for LYS $_{\text {bound }}$ could be controlled in lamb meat and beef simply by acidification of composite films placed on food surface. However, the designed $\mathrm{pH}$-triggered release mechanism did not work successfully in smoked salmon due to the liberation of LYSbound from non-acidified films in presence of salt used in curing. Further studies are needed to optimize film compositions (LYS, SPI, and LPI contents) and fix the amount of free and bound enzyme fractions in the films. Moreover, an industrial design of a special packaging is also needed to develop practical commercial applications for the developed delivery method. For example, integration of a simple acidification mechanism into packaging could enable activation of films in closed packages. This provides an additional antimicrobial effect to VP or MAP during transportation from market to home and enables extra safety for closed or opened packed food kept at home until consumption. The development of ActiHome packaging concept might expand the horizons of standard antimicrobial packaging by involving conscious consumers in the active packaging process. This helps development of valueadded personalized food products that help risk management for susceptible people such as pregnant women, elderly and immunosuppressed people.

Table 2

Mechanical properties of zein, zein-LPI and zein-SPI films.

\begin{tabular}{|c|c|c|c|c|c|c|}
\hline \multicolumn{3}{|c|}{$\begin{array}{l}\text { Incorporated concentration (mg/ } \\
\mathrm{cm}^{2} \text { ) }\end{array}$} & \multirow[t]{2}{*}{ Thickness $(\mu \mathrm{m})$} & \multirow[t]{2}{*}{ Tensile Strength (MPa) } & \multirow[t]{2}{*}{ Elongation (\%) } & \multirow[t]{2}{*}{ Young's modulus (MPa) } \\
\hline LYS & LPI & SPI & & & & \\
\hline- & - & - & $135.72 \pm 6.2$ & $6.40 \pm 0.9^{\mathrm{a}}$ & $1.36 \pm 0.1^{\mathrm{c}}$ & $470.29 \pm 38.6 a$ \\
\hline 0.7 & - & - & $126.69 \pm 3.3$ & $5.62 \pm 0.3^{\mathrm{ab}}$ & $1.52 \pm 0.1^{\mathrm{c}}$ & $370.14 \pm 30.5 b$ \\
\hline 0.7 & 4.5 & - & $119.94 \pm 2.9$ & $5.34 \pm 0.9^{b}$ & $3.88 \pm 0.5^{\mathrm{a}}$ & $138.75 \pm 23.1 c$ \\
\hline 0.7 & - & 4.5 & $146.11 \pm 2.9$ & $5.17 \pm 0.5^{\mathrm{b}}$ & $3.45 \pm 0.3^{b}$ & $150.74 \pm 20.5 c$ \\
\hline
\end{tabular}

$\overline{a-c}$ different letter at each column indicate statistially significant changes at $\mathrm{p}<0.05$. 


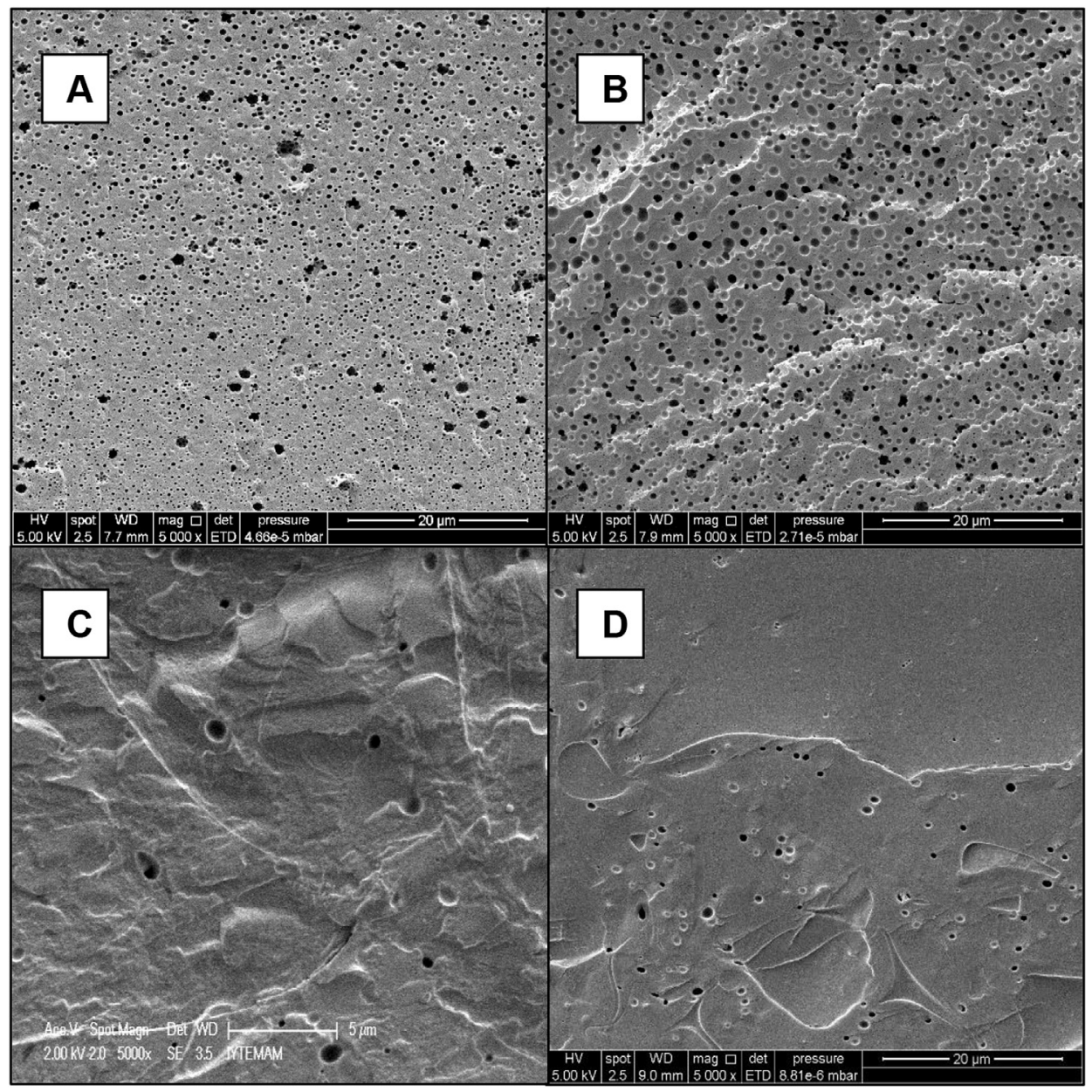

Fig. 5. SEM photographs of different films (Magnification x 5000; A: Control zein; B: zein with LYS; C: zein-LPI (4.5 mg/cm²) with LYS; D: zein-SPI (4.5 mg/cm²) with LYS).

\section{Acknowledgements}

We appreciate the Biotechnology and Bioengineering Application and Research Centre and the Centre for Materials Research (MAM) in İzmir Institute of Technology at İmir (Turkey) for providing their facilities during morphological characterization of films with SEM.

\section{Appendix A. Supplementary data}

Supplementary data related to this article can be found at https://doi.org/10.1016/j.foodhyd.2017.12.038.

\section{References}

Álvarez-Ordóñez, A., Leong, D., Hickey, B., Beaufort, A., \& Jordan, K. (2015). The challenge of challenge testing to monitor Listeria monocytogenes growth on ready-to-eat foods in Europe by following the European Commission (2014) Technical Guidance document. Food Research International, 75, 233-243.

Appendini, P., \& Hotchkiss, J. H. (1997). Immobilization of lysozyme on food contact polymers as potential antimicrobial films. Packaging Technology and Science, 10(5), 271-279.

Appendini, P., \& Hotchkiss, J. H. (2002). Review of antimicrobial food packaging. Innovative Food Science \& Emerging Technologies, 3(2), 113-126.

Arcan, I., Boyacı, D., \& Yemenicioğlu, A. (2017). The use of zein and its edible films for the development of food packaging materials. In Reference module in food sciences (pp. 1-11). Elsevier.

Arcan, I., \& Yemenicioğlu, A. (2007). Antioxidant activity of protein extracts from heat-treated or thermally processed chickpeas and white beans. Food Chemistry, 103(2), 301-312.

Argos, P., Pedersen, K., Marks, M. D., \& Larkins, B. A. (1982). A structural model for maize zein proteins. Journal of Biological Chemistry, 257(17), 9984-9990.

ASTM. (2002). Standard test method for tensile properties of thin plastic sheetingD882-02. Philadelphia, PA: ASTM, Annual Book of American Standard Testing Methods.

Aydemir, L. Y., \& Yemenicioğlu, A. (2013). Potential of Turkish Kabuli type chickpea and green and red lentil cultivars as source of soy and animal origin functional protein alternatives. LWT-Food Science and Technology, 50(2), 686-694.

Bower, C. K., Avena-Bustillos, R. J., Olsen, C. W., McHugh, T. H., \& Bechtel, P. J. (2006). Characterization of fish skin gelatin gels and films containing the antimicrobial enzyme lysozyme. Journal of Food Science, 71(5), M141-M145.

Boyacı, D., Korel, F., \& Yemenicioğlu, A. (2016). Development of activate-at-hometype edible antimicrobial films: An example pH-triggering mechanism formed for smoked salmon slices using lysozyme in whey protein films. Food Hydrocolloids, 60, 170-178.

Buchanan, R. L., \& Klawitter, L. A. (1990). Effects of temperature and oxygen on the growth of Listeria monocytogenes at pH 4.5. Journal of Food Science, 55(6), 1754-1756.

Cagri, A., Ustunol, Z. \& Ryser, E. T. (2001). Antimicrobial, mechanical, and moisture barrier properties of low $\mathrm{pH}$ whey protein-based edible films containing $\mathrm{p}$ aminobenzoic or sorbic acids. Journal of Food Science, 66(6), 865-871.

Cha, D. S., \& Chinnan, M. S. (2004). Biopolymer-based antimicrobial packaging: A review. Critical Reviews in Food Science and Nutrition, 44(4), 223-237.

Cha, D. S., Choi, J. H., Chinnan, M. S., \& Park, H. J. (2002). Antimicrobial films based on Na-alginate and א-carrageenan. LWT-Food Science and Technology, 35(8), 715-719.

D'Ostuni, V., Tristezza, M., De Giorgi, M. G., Rampino, P., Grieco, F., et al. (2016). Occurrence of Listeria monocytogenes and Salmonella spp. in meat processed products from industrial plants in Southern Italy. Food Control, 62, 104-109.

Dalgaard, P., \& Jørgensen, L. V. (1998). Predicted and observed growth of Listeria monocytogenes in seafood challenge tests and in naturally contaminated coldsmoked salmon. International Journal of Food Microbiology, 40(1), 105-115.

Davies, A. R. (1997). Modified-atmosphere packaging of fish and fish products. In Fish processing technology (pp. 200-223). US: Springer.

Di Ciccio, P., Meloni, D., Festino, A. R., Conter, M., Zanardi, E., Ghidini, S., et al. (2012). Longitudinal study on the sources of Listeria monocytogenes contamination in 
cold-smoked salmon and its processing environment in Italy. International Journal of Food Microbiology, 158(1), 79-84.

Duan, J., Park, S. I., Daeschel, M. A., \& Zhao, Y. (2007). Antimicrobial chitosanlysozyme (CL) films and coatings for enhancing microbial safety of mozzarella cheese. Journal of Food Science, 72(9), M355-M362.

Duffes, F. (1999). Improving the control of Listeria monocytogenes in cold smoked salmon. Trends in Food Science \& Technology, 10(6), 211-216.

Francis, G. A., \& Beirne, D. O. (1997). Effects of gas atmosphere, antimicrobial dip and temperature on the fate of Listeria innocua and Listeria monocytogenes on minimally processed lettuce. International Journal of Food Science \& Technology, 32(2), 141-151.

Gennadios, A., Hanna, M. A., \& Kurth, L. B. (1997). Application of edible coatings on meats, poultry and seafoods: A review. LWT-Food Science and Technology, 30(4), $337-350$.

Gram, L. (2001). Potential hazards in cold-smoked fish: Listeria monocytogenes. Journal of Food Science, 66(s7).

Guo, Y., Liu, Z., An, H., Li, M., \& Hu, J. (2005). Nano-structure and properties of maize zein studied by atomic force microscopy. Journal of Cereal Science, 41(3), 277-281.

Güçbilmez, C. M., Yemenicioğlu, A., \& Arslanoğlu, A. (2007). Antimicrobial and antioxidant activity of edible zein films incorporated with lysozyme, albumin proteins and disodium EDTA. Food Research International, 40(1), 80-91.

Han, J. H. (2000). Antimicrobial food packaging. Food Technology, 54(3), 56-65.

Han, J. H. (2003). Antimicrobial food packaging. In Novel food packaging techniques (pp. 50-70)

Joerger, R. D. (2007). Antimicrobial films for food applications: A quantitative analysis of their effectiveness. Packaging Technology and Science, 20(4), $231-273$

Koohmaraie, M., Whipple, G., Kretchmar, D. H., Crouse, J. D., \& Mersmann, H. J. (1991). Postmortem proteolysis in longissimus muscle from beef, lamb and pork carcasses. Journal of Animal Science, 69(2), 617-624.

Lu, H., Zhu, J., Li, J., \& Chen, J. (2015). Effectiveness of active packaging on control of Escherichia Coli 0157: H7 and total aerobic bacteria on iceberg lettuce. Journal of Food Science, 80(6), M1325-M1329.

Lynch, M. F., Tauxe, R. V., \& Hedberg, C. W. (2009). The growing burden of foodborne outbreaks due to contaminated fresh produce: Risks and opportunities. Epidemiology and Infection, 137(03), 307-315.

Mecitoglu, C.., Yemenicioğlu, A., Arslanoğlu, A., Elmacı, Z. S., Korel, F., \& Cetin, A. E. (2006). Incorporation of partially purified hen egg white lysozyme into zein films for antimicrobial food packaging. Food Research International, 39(1) $12-21$.

Mendes de Souza, P., Fernández, A., López-Carballo, G., Gavara, R., \& HernándezMuñoz, P. (2010). Modified sodium caseinate films as releasing carriers of lysozyme. Food Hydrocolloids, 24(4), 300-306.

Michaelsen, A. R., Sebranek, J. G., \& Dickson, J. S. (2006). Effects of microbial inhibitors and modified atmosphere packaging on growth of Listeria monocytogenes and Salmonella enterica Typhimurium and on quality attributes of injected pork chops and sliced cured ham. Journal of Food Protection, 69(11), $2671-2680$

Min, S., Rumsey, T. R., \& Krochta, J. M. (2008). Diffusion of the antimicrobial lysozyme from a whey protein coating on smoked salmon. Journal of Food Engineering, 84(1), 39-47.

Morton, J. D., Bickerstaffe, R., Kent, M. P., Dransfield, E., \& Keeley, G. M. (1999). Calpain-calpastatin and toughness in $M$. longissimus from electrically stimulated lamb and beef carcasses. Meat Science, 52(1), 71-79.

Okubo, K., Waldrop, A. B., Iacobucci, G. A., \& Myers, D. V. (1975). Preparation of lowphytate soybean protein isolate and concentrate by ultrafiltration. Cereal Chemistry, 52(2), 263-271.

Ouali, A., \& Talmant, A. (1990). Calpains and calpastatin distribution in bovine porcine and ovine skeletal muscles. Meat Science, 28(4), 331-348.

Ouattara, B., Simard, R. E., Piette, G., Bégin, A., \& Holley, R. A. (2000). Inhibition of surface spoilage bacteria in processed meats by application of antimicrobial films prepared with chitosan. International Journal of Food Microbiology, 62(1),
$139-148$

Padgett, T., Han, I. Y., \& Dawson, P. L. (1998). Incorporation of food-grade antimicrobial compounds into biodegradable packaging films. Journal of Food Protection, 61(10), 1330-1335.

Park, S. I., Daeschel, M. A., \& Zhao, Y. (2004). Functional properties of antimicrobial lysozyme-chitosan composite films. Journal of Food Science, 69(8), M215-M221.

Pérez-Pérez, C., Regalado-González, C., Rodríguez-Rodríguez, C. A., BarbosaRodríguez, J. R., \& Villaseñor-Ortega, F. (2006). Incorporation of antimicrobia agents in food packaging films and coatings. Advances in Agricultural and Food Biotechnology, 193-216.

Quintavalla, S., \& Vicini, L. (2002). Antimicrobial food packaging in meat industry Meat Science, 62(3), 373-380.

Rutherford, T. J., Marshall, D. L., Andrews, L. S., Coggins, P. C., Schilling, M. W., \& Gerard, P. (2007). Combined effect of packaging atmosphere and storage temperature on growth of Listeria monocytogenes on ready-to-eat shrimp. Food Microbiology, 24(7), 703-710.

Selling, G. W., Woods, K. K., Sessa, D., \& Biswas, A. (2008). Electrospun zein fibers using glutaraldehyde as the crosslinking reagent: Effect of time and temperature. Macromolecular Chemistry and Physics, 209(10), 1003-1011.

Shah, N. P. (2000). Effects of milk-derived bioactives: An overview. British Journal of Nutrition, 84(S1), 3-10.

Shukla, R., \& Cheryan, M. (2001). Zein: The industrial protein from corn. Industrial crops and products, 13(3), 171-192.

Smith, B., Larsson, J. T., Lisby, M., Müller, L., Madsen, S. B., Engberg, J., et al. (2011). Outbreak of listeriosis caused by infected beef meat from a meals \& hyphen;onwheels delivery in Denmark 2009. Clinical Microbiology and Infections, 17(1) $50-52$.

Sudagidan, M., \& Yemenicioğlu, A. (2012). Effects of nisin and lysozyme on growth inhibition and biofilm formation capacity of Staphylococcus aureus strains isolated from raw milk and cheese samples. Journal of Food Protection, 75(9), $1627-1633$.

Suppakul, P., Miltz, J., Sonneveld, K., \& Bigger, S. W. (2003). Active packaging technologies with an emphasis on antimicrobial packaging and its applications. Journal of Food Science, 68(2), 408-420.

Tsigarida, E., Skandamis, P., \& Nychas, G. J. (2000). Behaviour of Listeria monocytogenes and autochthonous flora on meat stored under aerobic, vacuum and modified atmosphere packaging conditions with or without the presence of oregano essential oil at $5^{\circ} \mathrm{C}$. Journal of Applied Microbiology, 89(6), 901-909.

Ünalan, I. U., Arcan, I., Korel, F., \& Yemenicioglu, A. (2013). Application of active zeinbased films with controlled release properties to control Listeria monocytogenes growth and lipid oxidation in fresh Kashar cheese. Innovative Food Science \& Emerging Technologies, 20, 208-214.

Ünalan, I. U., Korel, F., \& Yemenicioglu, A. (2011). Active packaging of ground beef patties by edible zein films incorporated with partially purified lysozyme and $\mathrm{Na}_{2}$ EDTA. International Journal of Food Science and Technology, 46(6), 1289-1295.

Vazquez-Boland, J. A., Kuhn, M., Berche, P., Chakraborty, T., Dominguez-Bernal, G., Goebel, W. et al. (2001). Listeria pathogenesis and molecular virulence determinants. Clinical Microbiology Reviews, 14, 584-640.

Vermeulen, A., Devlieghere, F., De Loy-Hendrickx, A., \& Uyttendaele, M. (2011) Critical evaluation of the EU-technical guidance on shelf-life studies for L. monocytogenes on RTE-foods: A case study for smoked salmon. International Journal of Food Microbiology, 145(1), 176-185.

Xu, W., Reddy, N., \& Yang, Y. (2007). An acidic method of zein extraction from DDGS Journal of Agricultural and Food Chemistry, 55(15), 6279-6284.

Yemenicioğlu, A., \& Cemeroğlu, B. (1999). Separation and thermal characterization of ionically and tightly cell-wall-bound pectin methylesterase from cucumbers (Cucumis sativus). Zeitschrift für Lebensmittel-Untersuchung und-Forschung A 208(5), 369-372.

Yemenicioglu, A., Özkan, M., \& Cemeroğlu, B. (1998). Partial purification and thermal characterization of peroxidase from okra (Hibiscus esculentum). Journal of Agricultural and Food Chemistry, 46(10), 4158-4163. 